\title{
Doppler ultrasound and giant cell arteritis
}

This article was published in the following Dove Press journal:

Clinical Ophthalmology

24 November 2010

Number of times this article has been viewed

\author{
Ana Marina Suelves' \\ Enrique España-Gregori ${ }^{1,2}$ \\ Jose Tembl ${ }^{3}$ \\ Stephanie Rohrweck' \\ Jose Maria Millán ${ }^{4}$ \\ Manuel Díaz-Llopis ${ }^{1,4,5}$ \\ 'Service of Ophthalmology, La Fe \\ University Hospital, Valencia, Spain; \\ ${ }^{2}$ Department of Optics, University of \\ Valencia, Valencia, Spain; ${ }^{3}$ Service of \\ Neurology, La Fe University Hospital, \\ Valencia, Spain; ${ }^{4}$ CIBERER, Ciber de \\ Enfermedades Raras, Valencia, Spain; \\ ${ }^{5}$ Faculty of Medicine, University \\ of Valencia, Valencia, Spain
}

Objective: To evaluate the utility of ultrasound in aiding the diagnosis of giant cell arteritis (GCA), in monitoring the response to corticotherapy, and in detecting early relapses.

Methods: A pilot study, prospective, included 10 patients with suspected GCA. All patients underwent ultrasound examination of both temporal arteries before temporal artery biopsy (TAB), 3 weeks after starting treatment, and 3 months after diagnosis. For this study, the histological findings alone were used to define if patients were suffering from GCA. The findings on ultrasound were compared with the results of biopsy. The best place to perform TAB was observed by ultrasound.

Results: All patients with positive biopsy were detected with ultrasound. No false positives were observed on ultrasound. The results presented give a sensibility, specificity, and positive predictive value of $100 \%$ for the use of ultrasound in the diagnosis of GCA. Two relapses were detected early by ultrasound during the follow-up.

Conclusions: This pilot study suggests that eco-doppler may be a useful tool in diagnosis and clinic follow-up in patients with suspected GCA.

Keywords: giant cell arteritis, ultrasound, temporal artery biopsy, optic nerve

Giant cell arteritis (GCA) is an ophthalmological emergency that sometimes poses a diagnostic challenge. Its most serious complication is irreversible visual acuity loss secondary to ischemic optic neuropathy that may become bilateral within a few days or weeks if a prompt diagnosis and treatment are not established. ${ }^{1}$ Traditionally, histopathological confirmation based on a temporal artery biopsy (TAB) has been regarded as the gold standard. In recent years, non-invasive imaging techniques such as high-resolution color Doppler ultrasound (CDU) have been applied in an attempt to overcome the limitations of $\mathrm{TAB},{ }^{2}$ which is an invasive technique with complications $(0.5 \%)$ fundamentally in the form of auriculo-temporal branch damage and skin necrosis, and offers only moderate sensitivity ( $70 \%-90 \%)$. In effect, $10 \%-30 \%$ of all patients with GCA remain undiagnosed with $\mathrm{TAB}$, due to the involvement of other extracranial branches of the carotid, failure to biopsy the affected trajectory owing to the patchy inflammation of the vessel, or failure to actually biopsy arterial tissue. Temporal artery CDU is able to identify three characteristic ultrasound features: 1) A periluminal hypoechogenic halo reflecting arterial wall edema (Figure 1); 2) Segmental arterial stenosis (Figure 2); 3) Arterial luminal occlusion in severe cases. The most specific finding $(85 \%-100 \%)$ is the periluminal halo, though the latter is scantly sensitive when isolatedly compared with the histological findings
C/Jose Vicente Casabán Sena, $n^{\circ} 2$, Esc 3 Pta 19, Xirivella, 46950 Valencia, Spain Tel +34630070737

Email ana.suelves@gmail.com 


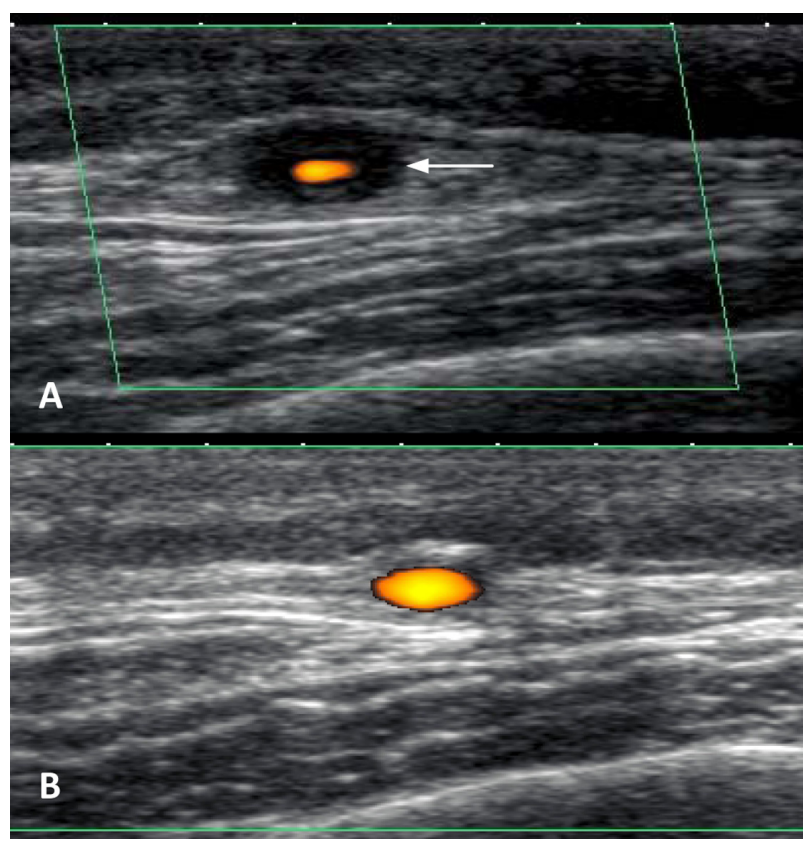

Figure I A) Cross-sectional Doppler ultrasound view of the right temporal artery. The arrow shows the hypoechogenic halo sign. B) Image 3 weeks after treatment, showing disappearance of the halo.

and clinical criteria. However, the sensitivity increases to $95 \%-100 \%$ on considering all three ultrasound features. ${ }^{3,4}$

We have begun a prospective pilot study with 10 cases, performing CDU (TOSHIBA APLIO XG, with a PLT1204BT high-resolution probe at $18 \mathrm{MHz}$ ) prior to TAB, after 3 weeks and after 3 months, to evaluate the usefulness of this imaging technique in GCA. The CDU was performed by the same user within the first three days after initial high-dose steroid administration. The TAB was accomplished along the temple, the day after CDU. The study series consisted of 4 males and 6 females, with a mean age of 76.5 years. CDU revealed some compatible sign in 6 cases (halo $=6$, stenosis $=5$, occlusion $=2$ ) - the biopsy diagnosing GCA in all of them. In the 4 cases with negative CDU findings, the biopsy also proved negative. Two relapses were detected early by ultrasound during the follow-up, with a recurrence of halo sign detected. In our experience, CDU prior to TAB increases the diagnostic yield, because it is able to identify

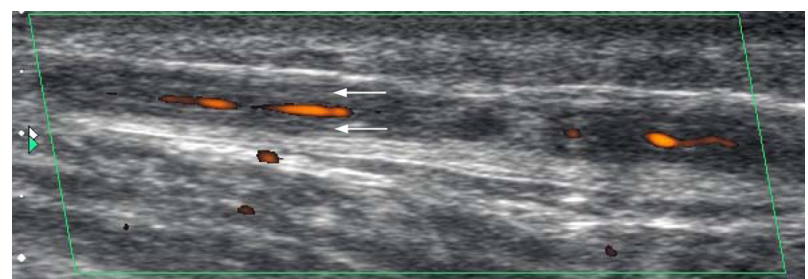

Figure 2 Longitudinal Doppler ultrasound view. Note the important narrowing of the arterial lumen due to vasculitic edema of the wall, with multiple stenotic areas.

the best biopsy target segment. After starting treatment, the patient response can be evaluated using CDU, based on the course of the ultrasound signs together with the clinical and laboratory test responses. In addition, CDU is able to detect disease relapse.

Thus, CDU may be useful in application to the initial diagnosis and follow-up of patients with GCA, in view of its innocuous nature, reproducibility, and 100\% correlation to the TAB findings in our series. Negative result in CDU could be used to spare biopsies. However, at present, we do not believe that CDU (with the risk implied by false-negative findings and user dependance) can fully replace TAB; rather, the two techniques complement each other. Prospective studies involving larger patient samples and longer follow-up, at least 2 years ${ }^{5}$ are needed to corroborate these findings.

\section{Disclosure}

No conflicts of interest were declared in relation to this paper.

\section{References}

1. Jonasson F, Cullen JF, Elton PA. Temporal arteritis: a 14-year epidemiological, clinical and prognostic study. Scott Med. 1979;24:111-117.

2. Kawasaky A, Purvin V. Giant cell arteritis: an updated review. Acta Opthalmol. 2009;87:13-32.

3. Karassa FB, Matsagas MI, Schmidt WA, Ioannidis JP. Meta-analysis test performance of ultrasonography for temporal arteritis. Ann Intern Med. 2009;142:359-369.

4. Schmidt WA, Möller DE, Gromnica-Ihle E. Color duplex ultrasound of the temporal artery: replacement for biopsy in temporal arteritis. Ophthalmologica. 2002;217:164-165.

5. Cullen JF, Chan BM, Wong CF, Chew WC. Giant cell (temporal) arteritis in Singapore: an occult case and the rationale of treatment. Singapore Med J. 2010;51:73-77.
Clinical Ophthalmology

\section{Publish your work in this journal}

Clinical Ophthalmology is an international, peer-reviewed journal covering all subspecialties within ophthalmology. Key topics include: Optometry; Visual science; Pharmacology and drug therapy in eye diseases; Basic Sciences; Primary and Secondary eye care; Patient Safety and Quality of Care Improvements. This journal is indexed on

\section{Dovepress}

PubMed Central and CAS, and is the official journal of The Society of Clinical Ophthalmology (SCO). The manuscript management system is completely online and includes a very quick and fair peer-review system, which is all easy to use. Visit http://www.dovepress.com/ testimonials.php to read real quotes from published authors. 